\title{
Investigating Reading Learning Strategies through Smartphones on Saudi Learners' Psychological Autonomy in Reading Context
}

\author{
Ali Abbas Falah Alzubi \\ Asst. Prof., Deanship of Preparatory Year, Najran University, Saudi Arabia, \\ aliyarmouk2004@gmail.com
}

\section{Manjet Kaur A/P Mehar Singh}

$\mathrm{PhD}$, School of Languages, Literacies, \& Translation, Univeristi Sains Malaysia, manjeet@usm.my

\author{
Abduljalil Nasr Hazaea \\ Asst. Prof., Deanship of Preparatory Year, Najran University, Saudi Arabia, \\ agaleel@gmail.com
}
This study investigated the impact of reading learning strategies (RLS) mediated by smartphone features and applications on the learners' psychological autonomy in English as a foreign language (EFL) reading context among undergraduates in Saudi Arabia. A total of 70 male students in two intact reading classes participated in this study. A questionnaire was used to collect the quantitative data from the participants prior to and after an interventional programme. The findings of the study revealed that employment of RLS mediated by smartphone features and applications promoted the learners' psychologically autonomous features of motivation, self-efficacy, agency, positive attitudes, desire to seek information, need for achievement in EFL reading context. It is recommended that a training programme on strategy use through the technology of smartphones should be highly considered in curricula design, teaching and learning methods, training programmes in order to empower learners to take charge of their own learning of EFL reading skills.

Keywords: psychological autonomy, reading learning strategies, reading skills, Saudi Arabia, smartphones

\section{INTRODUCTION}

Learning a second/foreign language is an inclusive process that requires learners to be constantly and continuously alert and able to deal with its various aspects on their own. Achieving this goal demands that learners make decisions about and be responsible for 
their own language learning, i.e., they should be able to set learning objectives, assess, reflect, and get feedback on their language learning (Benson \& Voller, 1997; Holec, 1981; Littlewood, 1996). Coffman and Klinger (2007) claim that learners in the $21^{\text {st }}$ century need to communicate, take charge of, create, and innovate in their own learning as they are required to be engaged in more independent online learning environments than before. In order for learners to perceive a second/foreign language appropriately regardless of issues of teacher centeredness, textbooks, time, and place, they need to be autonomous learners of the language where they are effectively motivated to seek for meaning and gain achievement, highly efficient, have positive attitudes to learn on their own in EFL context (Oxford, 1990, 2003). The learners' awareness and use of language learning strategies are emphasised as effective means that assist learners to take charge of their own learning where they are constantly alert, apply, and utilise the surrounding circumstances to deal with any texts they face, especially with the wide spread of smartphone technology and internet (Ceylan, 2015; Wasilewska, 2012).

Undergraduates in Saudi Arabia experience low levels of learner autonomy (LA) in EFL context attributed to lack of exposure, less motivation, lack of training programmes, limited time and place allocated for learning, lack of practice and use of reading inside and outside the classroom, inefficient teaching methods where the teacher controls the whole learning process, rote learning habits, and inappropriate learning textbooks (AlQahtani, 2016, Nezami, 2012, Tamer, 2013). These challenges have resulted in unsatisfactory levels of responsibility for learning and achievements, especially in reading skills (Rahman \& Alhaisoni, 2013). Therefore, this study investigated the learners' employment of reading learning strategies (RLS) mediated by smartphone features and applications to assist in the improvement of their psychologically autonomous features of motivation, agency, self-efficacy, attitudes, desire to seek for meaning, and need for achievement in EFL reading context.

\section{LITERATURE REVIEW}

\section{EFL reading}

Reading is considered as the most crucial skill in EFL context (Alderson, 1984; Mcdonough \& Shaw, 1993 as cited in Khaokaew, 2012). Mikulecky (2008) claims that effective reading is fundamental for success in acquiring another language because it is the basis of instruction in all aspects of language learning: writing, developing vocabulary, acquiring grammar, editing, and using computer-assisted language learning and mobile-assisted language learning (MALL) programs. Processing any text demands that learners are aware of RLS that assist in decoding and comprehending reading passages (Oxford, 1990). EFL reading in the Saudi context is problematic. The average results of TOEFL and IELTS tests proved to be the lowest in EFL reading among the Middle East (13 out 20; 4.8 out of 9) (ETS, 2016; IELTS, 2015) respectively. A number of researchers highlighted the importance of EFL learners' use of language learning strategies (LLS) to enhance autonomous learning and improve their reading competence and achievement (Alrabai, 2014; Al-Shumaimeri, 2003; Rahman \& Alhaisoni, 2013). 


\section{Language learning strategies in EFL reading}

Interest in language learning strategies (LLS) started in 1970s. The idea of LLS revolves around the concept of good language learners' employment of techniques to assist their language acquisition, competence, and proficiency (Bialystok, 1978; Rubin, 1975; Samida, 2012; Weinstein \& Mayer, 1986; Wenden, 1987). LLS are defined as the processes that learners employ to help them acquire, store, and retrieve information (Oxford, 1990). The learners' use of LLS (specific actions) makes 'learning easier, faster, more enjoyable, more self-directed, more effective and more transferable to new situations' (Oxford, 1990, p.8). Oxford believes that LLS can empower learners to learn on their own and help them gain self-confidence, and improve proficiency. Oxford (1990) developed a taxonomy of language learning strategies of six categories divided into direct and indirect strategies. Direct strategies, which involve direct learning and use of a new language, (Oxford, 1990), include memory strategies (MS), cognitive strategies (CS), and compensation strategies (CSs). MS are used for remembering and retrieving new information through creating mental linkages, applying images and sounds, reviewing well, and employing action. CS are applied to understand and produce the target language and involve the essential processes of practicing, receiving and sending messages, analysing, and creating structures for input and output. CSs are about using the language despite knowledge gaps and classified into guessing intelligently and overcoming limitations in speaking and writing. Indirect strategies, which 'contribute indirectly but powerfully to learning', refer to the implicit management and direction of the learning process by the learner and are subdivided into three groups: metacognitive strategies (MSs), affective strategies (AS), and social strategies (SS). MSs help coordinate the learning process through planning, arranging, focusing, and evaluating learners' own language learning. AS, which enable the regulation of emotions, are composed of lowering the learner's anxiety, encouragement, and taking emotional temperature (self-assessment to notice all emotions, avoid negative ones, and make the most of the positive one). SS are learning with others through asking questions, cooperating, and empathizing (Oxford, 1990, pp.14-15).

\section{Psychological autonomy}

Interest in learner autonomy (LA) has started in 1980s. Holec (1981, p.3) first defined LA as 'the ability to take charge of one's own learning.' and elaborated this definition in the learner's responsibility in all aspects of his/her language learning including determination of the language learning objectives, definition of the contents and progressions, selection of methods and techniques to be used, monitoring the procedure of acquisition, and evaluation of what has been acquired. Later, researchers inspired by Holec's concepualisation of LA, presented various perceptions, definitions, and models of LA in EFL contexts such as Benson (1997), Cotterall (1995), Dickinson (1987), Holec (1981), Little (1991), Oxford (2003), Pennycook (1997). Oxford (2003) proposed a more comprehensive systematic model for LA including four perspectives: technical perspective, psychological perspective, socio-cultural perspective, and political-critical perspective. Oxford's model emphasises four main themes in each perspective: context, agency, motivation, and learning strategies (Oxford, 2003, pp. 80-81). 
Psychological autonomy (PA) investigates the mental and emotional features of learners and combines thee psychological characteristics of the individual (Oxford, 2003). These psychological characteristics involve the learners' motivation (extrinsic and intrinsic motivation (Ryan \& Deci, 2000), self-efficacy (learner is capable to produce in the learning of another language on his/her own), agency (having a goal to perform), a desire to seek meaning (Frankl, 1997); positive attitudes; and need for achievement (Oxford, 2003). Oxford (2003) argues that learning strategies in PA are the psychological features of the individual that can change through practice and strategy instruction (Oxford, 2003). Context in PA refers to second/foreign language environment (Oxford, 2003). Agency refers to the learners' beliefs to organise and excite the courses of action required to produce given attainments (Bandura, 1997, p.3). Motivation in PA is the learners' freedom to play by their own rules while learning. Learning strategies in PA are the specific steps that are teachable through strategy instruction or learner training and can improve learners' sense of agency, self-efficacy judgments, motivation, confidence, and L2 performance (Oxford, 2003). In this study, context will be foreign language environment (Saudi Arabia) where the foreign language is not practised by the majority (Green \& Oxford, 1995). Agency will be represented in the learners' employment of RLS through their own smartphone features and applications in the learning of EFL reading skills. Motivation will be the learners' ability to direct their own learning of reading skills based on external motives such as rewards and internal motives such as enjoyment of learning reading skills through their own smartphones regardless of time and place. Learning strategies will be reading learning strategies (RLS) of memory strategies (MS), cognitive strategies (CS), compensation strategies (CSs), metacognitive strategies (MSs), and affective strategies (AS) that concern the development of PA in EFL reading context.

\section{Smartphones}

Mobiles have been seen as helping devices in language learning due to the relatively low cost and increasing power of mobile phones that have remarkably captured the researchers' attention to support language learning (Chinnery, 2006; Kukulska-Hulme \& Traxler, 2005; Reinders, 2010); constant and immediate help, inclusive education, and various uses of technology (Kukulska-Hulme, 2016); exposure to the use and practice of language (Almekhlafy \& Alzubi, 2016), the disappearance of borders of time, and place (Selwyn, 2010). Smartphones provide a blueprint for autonomous learning, i.e., when learners employ their own smartphones, it makes them feel more responsible for and in the control of their own language learning (Reinders, 2010). Reinders and Hubbard (2013) emphasise the role of technology such as smartphones in developing learner autonomy (LA) in two aspects: free and ubiquitous access to appropriate resources and the necessary learning skills. Previous literature showed that EFL learners preferred to use mobile phones in language messaging and reading (Thornton, \& Houser, 2003), the delivery of vocabulary materials (Chen, \& Hsieh, 2008), the use of camera to explain idioms and share with friends via wiki (Wong, Chin, Tan, \& Liu, 2010), meanings of words (Godwin-Jones, 2011), reflection on daily life activities (Palfreyman, 2012), the extension of learning out of the classroom anywhere anytime (Rahimi \& Miri, 2014), interaction with peers and teacher and exposure to language (Almekhalfy \& Alzubi, 
2016); pronunciation, and parts of speech (Hazaea \& Alzubi, 2016). The research also showed that learners used mobiles to aid their language in guessing from context and dictionary use (Seddigh \& Shokrpur, 2012), personlising language learning process, sharing knowledge, driving away boredom, and spurring up creativity (Ahmed, 2015), and enhancing code breaking and text participation practices (Hazaea \& Alzubi (2016).

Although EFL learners in the Saudi context have a high tendency to take charge of their own language learning, the level of learner autonomy (LA) is not encouraging because of the lack of learners' training programme (Al Asmari, 2013; Alzubi, Manjet, \& Pandian, 2017; Farooq, 2013; Tamer, 2013). Therefore, the current study will examine the use of reading learning strategies (RLS) mediated by smartphone features and applications that relate to EFL reading skills and contribute to the perspective of psychological autonomy (PA) in terms of motivation, self-efficacy, agency, positive attitudes, desire to seek information, and need to achieve. The reading learning strategies (RLS) will include the employment of five strategies: memory strategies (MS), cognitive strategies (CS), compensation strategies (CSs), metacognitive strategies (MSs), and affective strategies (AS) mediated by the smartphone features and applications of dictionaries, WhatsApp, internet search engines, camera, notes, and recorders both inside and outside the classroom. In the light of literature, the current study will address the following research question: Is there any significant relationship between the use of reading learning strategies through smartphones and psychological autonomy among Saudi undergraduates in EFL reading context?

\section{METHOD}

A quantitative research design was used sequentially to collect the data through a pre and post questionnaire in the study. The questionnaire collected data on the use of RLS mediated by smartphones that impact the learners' psychological autonomy (PA) before and after the interventional programme in EFL reading context.

\section{Sample}

The current study involved undergraduates enrolled in the Deanship of Preparatory Year (PYP) at Najran University in Saudi Arabia. Each year, around 700 male students who finish high school in the science stream enter PYP. $95 \%$ of the PYP students are Saudi and 5\% are granted for other Arab nationalities, who most probably live in Saudi Arabia such as Yamani, Sudanese, Syrian, Egyptian, etc. Preparatory Year is a two-semester programme where students study skills such as English, mathematics, computer, and communication, before they specialise in the faculties of medicine, engineering, computer, and administrative sciences. Purposive sampling was applied to choose the sample of the study based on the most comprehensive understanding that it could provide and taking into consideration all participants who are accessible, most representative of the population, and can provide rich information that serves the objective of the study (Fraenkel \& Wallen, 2008; Patton, 2008). The sample consisted of two intact reading classes in total of 70 students: 35 in the experimental group and 35 in the control group. The two classes shared similar features in terms of ages, demography, education level, and gender (Etikan, Musa, \& Alkassim, 2016; Kemper, 
Stringfield, \& Teddlie, 2003). Preparatory Year undergraduates share a number of common features. They are homogeneous in terms of educational background (science stream at high school), age (18-20), gender (male) because of gender-based segregation of education, nationality (Saudi), mother tongue (Arabic), foreign language (English), and level (first semester in the first year).

Participation in this study was voluntary. The researcher provided the participants with a participation statement document detailing the information of the study for their records to acknowledge their participation in the research. The researcher works as a lecturer and teaches English language at PYP in Najran University. The roles of the researcher were represented by teaching the control group to make sure that participants in the control group did not get RLS strategy use training and did not employ smartphone features and applications in their learning of EFL reading skills. The researcher also distributed the questionnaires to the control group.

\section{Training programme}

A training programme was held for the participants in the experimental group in order to maximise the hoped benefits and assist them in the employment of RLS mediated by smartphone features and applications appropriately. A qualified teacher conducted the training programme for the experimental group. Participants in the experimental group were trained in the first three weeks on how to employ RLS through smartphones in relation to the textbook. The training programme was conducted in the first three weeks over ten sessions. In these sessions, the participants received training on the RLS: memory strategies, cognitive strategies, compensation strategies, metacognitive strategies, and affective strategies by Oxford (1990). In details, strategy use training was based on Oxford's (1990) model that includes seven implementing steps of strategy use training: determining the learners' needs and resources available for training; assigning the targeted strategies; considering the benefits of strategy use training and the motivational issues; preparing training materials and activities; conducting strategy use training; and evaluating and revising strategy use training. Training included activities based on the content to be covered in the syllabus breakdown of Basic Reading Power 1 (Jeffries \& Mikulecky, 2014) in the 2017- 2018 fall academic year and the parallel strategies that will be identified to be taught.

\section{Instrument}

The current study examined the use of reading learning strategies (independent variables) mediated by smartphone features and applications that relate to EFL reading skills and contribute to the perspective of psychological autonomy (dependent variable) in terms of motivation, self-efficacy, agency, positive attitudes, desire to seek information, and need to achieve. Data were collected through a pre and post questionnaire. The questionnaire prior to the intervention was administered in the first week to the experimental and control group, and then the strategy use interventional programme was implemented to the experimental group for 12 weeks. Following the interventional programme, the post questionnaire was administered to the experimental and control group. The questionnaire was distributed as a hard copy to the control group 
and experimental group inside the classroom with the help of the teacher. The questionnaire consisted of two domains. The first domain included an adapted version of Oxford's (1990) Strategy Inventory of Language Learning (SILL). It involved five substrategies: memory strategies $(n=10)$, cognitive strategies $(n=15)$, compensation strategies $(n=4)$, metacognitive strategies $(n=9)$, and affective strategies $(n=6)$ totaling 44 items, specific to the learning of reading skills that contribute to learners' psychological autonomy (PA). The second domain of the questionnaire included the psychological autonomy (PA) that consisted of 19 items that were developed by the researcher grounded on Oxford $(1990,2003)$ and Holec (1981). The questionnaire indicates how often learners employ RLS mediated by smartphones in EFL reading that impact their PA on a five-Likert scale: ('1' never, '2' rarely, '3' sometimes, '4' often, '5' always).

Reliability and validity of the RLS and PA questionnaire was checked through Factor Analysis and Cronbach's alpha. The Factor analysis was carried out using Pearson Correlation to validate the items' grouping in relation to the items of PA. The items were classified according to their loading to PA based on the level of significance $\left(0.01^{* *}, 0.05^{*}\right)$. As a result, 19 items were most overloaded on PA and two items were excluded as they had low loadings. Following the factor analysis, the questionnaire was administered to a sample of reading class $(n=32)$ other than those who participated in this study. The Cronbach's alpha of the scale registered a total of 94 .

\section{FINDINGS}

It must be noted that 70 students were registered in the two reading classes i.e., 35 students in each group. Therefore, the 70 students were assumed to participate in the study as an experimental and a control group. However, only 64 participants appeared in the two classes (32 in each class) and completed the pre RLS and PA questionnaire before the interventional programme. Moreover, the 64 students decreased to 59: 30 participants in the experimental group and 29 participants in the control group attributed to withdrawal, depriving form the course, and/or dropping the course or semester.

Research Question: Is there any significant relationship between the use of reading learning strategies through smartphones and psychological autonomy among Saudi undergraduates in EFL reading context?

The following table (Table 1) shows the data analysis of the use of reading learning strategies (RLS) and psychological autonomy (PA) prior to the interventional programme. 
Table 1

Analysis of Pre RLS and PA Questionnaire

\begin{tabular}{|c|c|c|c|c|c|c|c|c|c|}
\hline Domain & & Group & $\mathrm{N}$ & Mean & $\begin{array}{l}\text { St. } \\
\text { Deviation }\end{array}$ & $\mathrm{t}$ & df & $\begin{array}{l}\text { Sig. (2- } \\
\text { tailed) }\end{array}$ & $\begin{array}{l}\text { St. Error } \\
\text { Difference }\end{array}$ \\
\hline \multirow{12}{*}{ RLS } & & Experimental & 32 & 2.52 & .671 & \multirow{2}{*}{.554} & \multirow{2}{*}{62} & \multirow{2}{*}{.581} & \multirow[b]{2}{*}{.164} \\
\hline & Memory Strategies & Control & 32 & 2.43 & .637 & & & & \\
\hline & \multirow{3}{*}{ Cognitive strategies } & Experimental & 32 & 2.69 & .636 & \multirow{2}{*}{.318} & \multirow{2}{*}{62} & \multirow{2}{*}{.752} & \multirow{2}{*}{.155} \\
\hline & & Control & 32 & 2.65 & .600 & & & & \\
\hline & & Experimental & 32 & 2.46 & .791 & \multirow{2}{*}{$-1.661-$} & \multirow{2}{*}{62} & \multirow{2}{*}{.102} & \multirow{2}{*}{.224} \\
\hline & \multirow[t]{2}{*}{ Compensation strategies } & Control & 32 & 2.84 & .991 & & & & \\
\hline & & Experimental & 32 & 2.72 & .577 & \multirow{2}{*}{$-.878-$} & \multirow{2}{*}{62} & \multirow{2}{*}{.383} & \multirow{2}{*}{.146} \\
\hline & \multirow[t]{2}{*}{ Metacognitive strategies } & Control & 32 & 2.84 & .594 & & & & \\
\hline & & Experimental & 32 & 2.67 & .621 & \multirow{2}{*}{$-.104-$} & \multirow{2}{*}{62} & \multirow{2}{*}{.917} & \multirow{2}{*}{.150} \\
\hline & Affective strategies & Control & 32 & 2.68 & .579 & & & & \\
\hline & \multirow[t]{2}{*}{ Overall } & Experimental & 32 & 2.61 & .501 & \multirow[t]{2}{*}{$-.231-$} & \multirow[t]{2}{*}{62} & \multirow[t]{2}{*}{.818} & \multirow[t]{2}{*}{.122} \\
\hline & & Control & 32 & 2.68 & .472 & & & & \\
\hline \multirow[t]{2}{*}{ PA } & & Experimental & 32 & 2.70 & .655 & \multirow[t]{2}{*}{$-.282-$} & \multirow[t]{2}{*}{62} & \multirow[t]{2}{*}{.779} & \multirow[t]{2}{*}{.128} \\
\hline & & Control & 32 & 2.74 & .315 & & & & \\
\hline
\end{tabular}

According to Table 1, there are no significant differences in the scores of RLS between the experimental group $(\mathrm{M}=2.61, \mathrm{SD}=0.501)$ and control group $(\mathrm{M}=2.68, \mathrm{SD}=0.472)$ : $\mathrm{t}(62)=-.231-, \mathrm{p}=0.818$ prior to the interventional programme. The table also shows that no statistically significant differences exist in the scores of psychological autonomy (PA) between the experimental group $(\mathrm{M}=2.70, \mathrm{SD}=0.655)$ and control group $(\mathrm{M}=2.74$, $\mathrm{SD}=0.315) ; \mathrm{t}(62)=-.282-, \mathrm{p}=.779$ respectively. These statistics indicate the equality which both groups: experimental and control share before the interventional programme. This result proves that both groups: experimental and control experience an equivalent use of RLS and PA prior to the interventional programme and ensures that both groups are similar, thus adding to the groups' homogeneity.

\section{Post RLS and PA questionnaire}

Table 2 shows the data analysis of the RLS and PA questionnaires obtained after the interventional programme. Table 2 displays the independent t-test, significance, and effect size of the programme. 
Table 2

Analysis of Post LLS Questionnaire

\begin{tabular}{|c|c|c|c|c|c|c|c|c|c|}
\hline \multirow[t]{2}{*}{ Domain } & & \multirow{2}{*}{ Group } & \multirow[b]{2}{*}{$\mathrm{N}$} & & \multirow[b]{2}{*}{$\mathrm{t}$} & \multirow[b]{2}{*}{ df } & & \multirow{2}{*}{$\begin{array}{l}\text { Size Effect (Eta } \\
\text { Squared) }\end{array}$} \\
\hline & & & & Mean & $\begin{array}{l}\text { St. } \\
\text { Deviation }\end{array}$ & & & $\begin{array}{l}\text { Sig. (2- } \\
\text { tailed) }\end{array}$ & \\
\hline \multirow{12}{*}{ RLS } & Memory Strategies & Experimental & 30 & 3.78 & .588 & 5.263 & 57 & .000 & .327 \\
\hline & & Control & 29 & 3.07 & .423 & & & & \\
\hline & Cognitive Strategies & Experimental & 30 & 3.96 & .326 & 7.801 & 57 & .000 & .516 \\
\hline & & Control & 29 & 3.26 & .363 & & & & \\
\hline & Compensation & Experimental & 30 & 3.27 & .529 & 1.282 & 57 & .205 & .028 \\
\hline & Strategies & Control & 29 & 3.09 & .552 & & & & \\
\hline & Metacognitive & Experimental & 30 & 3.92 & .464 & 6.124 & 57 & .000 & .397 \\
\hline & Strategies & Control & 29 & 3.28 & .327 & & & & \\
\hline & Affective Strategies & Experimental & 30 & 3.96 & 646 & 5.880 & 57 & .000 & .378 \\
\hline & & Control & 29 & 3.14 & .385 & & & & \\
\hline & & Experimental & 30 & 3.78 & .325 & 9.677 & 57 & .000 & .622 \\
\hline & Overall & Control & 29 & 3.17 & .219 & & & & \\
\hline \multirow[t]{2}{*}{ PA } & & Experimental & 30 & 4.08 & .477 & 7.664 & 57 & .000 & \\
\hline & & Control & 29 & 3.31 & .250 & & & & \\
\hline
\end{tabular}

Table 2 shows that $76 \%$ of the participants in the experimental group employed RLS through smartphones $(\mathrm{M}=3.78, \mathrm{SD}=.325)$ compared with $63 \%$ in the control group $(\mathrm{M}=3.17, \mathrm{SD}=.219)$ who learned using traditional methods. Table 2 also shows that 82 $\%$ of participants in the experimental group $(\mathrm{M}=4.08, \mathrm{SD}=.477)$ have improved their autonomous features of psychology better compared with $66 \%$ in the control group $(\mathrm{M}=3.31, \mathrm{SD}=.250)$. It is also clear in Table 2 that the use of RLS by the experimental group which utilised smartphone features and applications in the EFL reading course compared with the control group who learned using traditional methods proved to be significant $(\mathrm{t}(57)=6.060, \mathrm{p}=.000)$. In more details, memory strategies (MS), cognitive strategies (CS), metacognitive strategies (MSs), and affective strategies (AS) scored significant differences at the level of (.000). However, compensation strategies (CSs) did not register any significance $(\mathrm{t}(57)=1.282, \mathrm{p}=.205)$. In addition, Table 2 displays that the use of PA proved to have significant differences in favour of the experimental group $(\mathrm{t}(57)=7.664, \mathrm{p}=.000)$ after the interventional programme. Learners in the experimental group managed to identify the learning goals and objectives and define the learning contents. They could also arrange and plan learning reading effectively and define appropriate methods and techniques. In addition, their abilities to monitor mistakes and errors and evaluate progress in reading learning improved. They used various ways to process information and knowledge and thus produce in the foreign language. Further to that, they showed high level of self-esteem, self-encouragement, anxiety reduction, tolerance of ambiguity, awareness of negative attitudes and feelings.

The effect size of the programme was measured using Eta squared after the interventional programme. It must be noted that the effect size was calculated after comparing the performance of the experimental and control group after the interventional programme. According to Cohen (1988), the results indicate that the programme was moderately effective (.622) as shown in Table 2. The Correlation Bivariate (Pearson Correlation) analysis was applied to correlate the use of RLS and PA 
after the interventional programme. The results of analysis show that the correlation between RLS and PA is at the level of 0.01 and proved to be significant $\left(.770^{* *}\right)$. Therefore, this is a strong indication about the role that language learning strategies play in the enhancement of the learners' autonomous learning characteristics.

\section{DISCUSSION}

The findings of the study have proved that the interventional programme on RLS strategy use through smartphones has assisted learners to better employ RLS on their own. They have learned how to store and retrieve new information, and perceive and produce information on their own. They also have become more able to overcome any language gaps and continue with tasks. In addition, they could decide upon the goals and objectives of reading tasks, correct mistakes, monitor, and evaluate their learning of EFL reading. In addition, they have learned how to control their feelings and attitudes toward language learning. The learners' improvement in the use of RLS has promoted their autonomous learning features of PA. Learners enjoyed the use of their smartphones to employ RLS on their own inside and outside the classroom. They have also become more capable to produce in the learning of EFL reading skills on their own. Their desire to read and seek for meaning, and to achieve has increased.

These findings are further confirmation of what previous research and literature reported on the relationship between language learning strategies (LLS) and learner autonomy (LA) in EFL context (Ceylan, 2015, 2017; Chen \& Pan, 2015; Fedderholdt, 1997; Hismanoglu, 2000; Holec, 1981; Nguyen \& Gu, 2013; O’Malley \& Chamot, 1990; Oxford, 1990, 2003; Reinders \& Hubbard, 2013; Salehi, Ebrahimi, Sattar, \& Shojaee, 2015; Su \& Duo, 2010; Timirbaeva, 2013; Wasilewska, 2012). The learners' employment of RLS mediated by smartphones has promoted their psychologically autonomous features of motivation, encouragement, self-reliance, responsibility towards learning a second/foreign language. Language learning strategies are indicators of how much autonomous EFL learners are who work out problems and tasks that face by them in the process of learning a second/foreign language (Hismanoglu, 2000). Chen and Pan (2015) emphasised this relationship in their study and reported that the more language learning strategies (LLS) EFL learners employ, the higher levels of ability, responsibility, and activities they enjoy.

The findings of the current study are coherent with a number of previous studies that investigated the use of LLS to assist in the learning of a second/foreign language where learners should explicit more autonomous learning roles. To explain, Su and Duo (2010) also reported that the use of metacognitive, affective and social strategies can predict the self-directed language learning in which learners claim more responsibility, independence, charge of their own language learning. In addition, Timirbaeva (2013) emphasized the role of LLS in elevating the notion that learners who learn on their own managed to know to learn on their own in terms of procedures and techniques. Nguyen and $\mathrm{Gu}$ (2013) also indicated that the strategy-based instruction programmes are plausible choices for the promotion of learner autonomy. Moreover, the strong relationship between the use of RLS and PA in the current study is supported by Ceylan 
(2015, 2017) and Balkir (2007) who claimed the role of strategy use training in improving the learners' perceptions of responsibility. That is to say participants who tend to use LLS more frequently would show a sign of learners' development in the level of language learning autonomy. Using language learning strategies such as metacognitive strategies (MSs) by distance learning students would enable them to foster autonomy (White, 1995), to plan and evaluate their language learning and to have more interaction and communication with other people (Mistar, 2015).

\section{CONCLUSION AND RECOMMENDATIONS}

The current study employed an interventional programme on RLS strategy use to assist the EFL learners to tackle all learning processes of reading skills related to information storage, retrieval, perception, production, gaps, monitoring, evaluation, feelings, and attitudes on their own. The smartphone features and applications facilitated the use of RLS inside and outside the classroom. The learners' levels of improvement in using RLS through smartphones regardless of place and time correlated positively with their learning features of psychological autonomy.

The findings of the current study could also serve as a strong base to take further actions to vary the EFL learning methods through allowing the use of smartphone features and applications as important parties in the learning process of EFL reading skills inside and outside the classroom. Future EFL reading courses can be incorporated with the integration of smartphones. The findings of the current study provide university authorities with a comprehensive picture on how the explicit use of strategy mediated by smartphones can impact the EFL readers' psychological autonomy (PA) in terms of motivation, self-efficacy, agency, responsibility, desire to seek for knowledge, positive attitudes, and need for achievement.

\section{REFERENCES}

Ahmed, M. D. (2015). Can Smartphones Pave the Path towards EFL Competence for Saudi College Students? Education and Linguistics Research, 1(2), 120-144.

Al Asmari, A. (2013). Practices and Prospects of Learner Autonomy: Teachers' Perceptions. English Language Teaching 6(3), 1-10.

Al-Qahtani, A. (2016). Why Do Saudi EFL Readers Exhibit Poor Reading Abilities? English Language and Literature Studies, 6(1), 1-15.

Almekhlafy, A. \& Alzubi, A. A. F. (2016). Mobile-Mediated Communication a Tool for Language Exposure in EFL Informal Learning Settings. Arab World English Journal, 7(1), 388-407.

Alrabai, F. (2014). Motivational Practices in English as a Foreign Language Classes in Saudi Arabia: Teachers Beliefs and Learners Perceptions. Arab World English Journal, 5(1), 21-37.

Al-Shumaimeri, Y. A. (2003). A study of Classroom Exposure to oral pedagogic tasks in relation to the motivation and performance of Saudi secondary school learners of 
English in a context of potential curriculum reform (doctoral dissertation). University of Leeds, UK.

Alzubi, A. A. F., Manjet, K., \& Pandian, A. (2017). The Use of Learner Autonomy in English as a Foreign Language Context among Saudi Undergraduates Enrolled in Preparatory Year Deanship at Najran University. Advances in Language and Literary Studies, 8(2), 152-160.

Balkır, N. (2007). An investigation into the effects of learner training and awareness building activities on learners' perceptions of responsibility in learning English (master's Thesis). Çanakkale Onsekiz Mart University, Turkey.

Bandura, A. (1997). Self-efficacy: the Exercise of Control. New York: Freeman.

Benson, P. (1997). The philosophy and politics of learner autonomy. In P. Benson, \& P. Voller (Eds.), Autonomy and independence in language learning (pp. 18-34). London: Longman.

Benson, P. \& P. A. Voller (1997). Independence in Language Learning. London: Longman.

Bialystok, E. (1978). A theoretical model of second language learning. Language Learning, 28(1), 69-83.

Ceylan, N. O. (2015). Fostering learner autonomy. Procedia-Social and Behavioral Sciences, 199, 85-93.

Ceylan, N. O. (2017). Does Training Learners on Language Learning Strategies Have Any Effect on Language Achievement? European Journal of Sustainable Development, 6(4), 405-415.

Chen, H.-I., \& Pan, H.-H. (2015). Learner Autonomy and the Use of Language Learning Strategies in a Taiwanese Junior High School. Journal of Studies in Education, 5(1), 5264.

Chen, N.-S., \& Hsieh, S.-W. (2008). Effects of short-term memory and content representation type on mobile language learning. Language Learning and Technology $12(3), 93-113$.

Chinnery, G. M. (2006). Emerging Technologies: Going to the MALL (Mobile Assisted Language Learning). Language Learning \& Technology, 10(1), 9-16.

Coffman, T., \& Klinger, M. B. (2007). Utilizing virtual worlds in education: The implications for practice. International Journal of Social Sciences, 2(1), 29-33.

Cotterall, S. (1995). Readiness for Autonomy: Investigating Learner Beliefs. System, 23(2), 195-205.

Dickinson, L. (1995). Autonomy and Motivation a Literature Review. System, 23(2), 165-174. 
Etikan, I., Musa, S. A., \& Alkassim, R. S. (2016). Comparison of convenience sampling and purposive sampling. American Journal of Theoretical and Applied Statistics, 5(1), $1-4$.

Farooq, M. U. (2013). Effects of learner autonomy on teaching practices and outcomes in an ELT classroom. European Journal of Scientific Research, 94, 316-330.

Fraenkel, J.R., \& Wallen, N.E. (2008). How to Design and Evaluate Research in Education. ( $7^{\text {th }}$ ed.). New York: McGraw-Hill International Edition.

Frankl, V.E. (1997). Man's Search for Meaning. Revised and updated edition. New York: Washington Square Press.

Godwin-Jones, R. (2011). Emerging Technologies: Mobile Apps for Language Learning. Language Learning \& Technology, 15(2), 2-11.

Hazaea, A. N., \& Alzubi, A. A. (2016). The Effectiveness of using mobile on EFL learners' reading practices in Najran University. English Language Teaching, 9(5), 821.

Hismanoglu, M. (2000). Language learning strategies in foreign language learning and teaching. The Internet TESL Journal, 6(8), 12-12.

Holec, H. (1981). Foreign Language Learning. Oxford: Pergamon Press.

Jeffries, L., \& Mikulecky, B. (2014). Reading Power 1 ( $3^{\text {rd }}$ ed.). UK: Pearson Longman.

Kemper, E. A., Stringfield, S., \& Teddlie, C. (2003). Mixed methods sampling strategies in social science research. In A. Tashakkori \& C. Teddlie (Eds.), Handbook of mixed methods in social and behavioral research (pp. 273-296). Thousand Oaks, CA: Sage.

Khaokaew, B. (2012). An investigation of explicit strategy instruction on EFL reading of undergraduate English majors in Thailand (doctoral dissertation).University of Bedfordshire, Luton, UK.

Kim, H., \& Kwon, Y. (2012). Exploring smartphone applications for effective mobileassisted language learning. Multimedia-Assisted Language Learning, 15(1), 31-57.

Kukulska-Hulme, A. (2012). Language learning defined by time and place: A framework for next generation designs. In E. Diaz-Vera, Javier (ed.). Left to my own devices: Learner autonomy and Mobile Assisted Language Learning. Innovation and leadership in English language teaching, 6 (pp. 1-13). UK: Emerald Group Publishing Limited.

Kukulska-Hulme, A. (2016). Mobile Assistance in Language Learning: A critical appraisal. In A., Palalas, \& M., Ally, (eds.), The International Handbook of MobileAssisted Language Learning (pp. 138-160). Beijing: China Central Radio \& TV University Press Co., Ltd.

Kukulska-Hulme, A., \& Traxler, J. (2005). Mobile learning: A handbook for educators and trainers. London: Routledge. 
Little, D. (1991). Autonomy: Definitions, Issues and Problems. Dublin: Authentik.

Littlewood, W. (1996). "Autonomy": An Anatomy and a Framework. System, 24(4), 427-435.

Mikulecky, B. S. (2008). Teaching reading in a second language. Pearson Longman. Available at http://www.longmanhomeusa.com/content/FINAL-LO\%20RES-MikuleckyReading\%20Monograph\%20.pdf

Mistar, J. (2015). Maximing Learning Strategies To Pomote Learner Autonomy. TEFLIN Journal, 12(1), 88-100.

Nezami, S. R. A. (2012). A critical Study of Comprehension Strategies and General Problems in Reading Skill Faced by Arab EFL Learners with Special Reference to Najran University in Saudi Arabia. International Journal Social Science and Education, 2(3), 306-316.

Nguyen, L. T. C., \& Gu, Y. (2013). Strategy-based instruction: A learner-focused approach to developing learner autonomy. Language Teaching Research, 17(1), 9-30.

O'Malley, J. M., \& Chamot, A. U. (1990). Learning Strategies in Second Language Acquisition. Cambridge: Cambridge university press.

Oxford, R. (2003). Toward a more systematic model of L2 learner autonomy. In D. Palfreyman \& R. Smith (Eds.), Learner autonomy across cultures: language education perspectives (pp. 75-91). New York: Palgrave Macmillan.

Oxford, R. L. (1990). Language learning strategies: what every teacher should know. Boston: Heinle and Heinle.

Palfreyman, D. M. (2012). Chapter Eight Bringing the World into the Institution: Mobile Instructional Learning for Staff and Students. Left to my own Devices: Learner Autonomy and Mobile-Assisted Language Learning: Learner Autonomy and Mobileassisted Language Learning, 6, 163.

Patton, M.Q. (2008). Qualitative research and evaluation methods. Newbury Park CA: Sage.

Pennycook, A. (1997). Cultural Alternatives and Autonomy. In P. Benson \& P. Voller (Eds.), Autonomy and Independence in Language Learning (pp. 35-53). London: Longman.

Rahimi, M., \& Miri, S. S. (2014). The impact of mobile dictionary use on language learning. Procedia-Social and Behavioral Sciences, 98, 1469-1474.

Rahman, M. M., \& Alhaisoni, E. (2013). Teaching English in Saudi Arabia: prospects and challenges. Academic Research International, 4(1), 112-118.

Reinders, H., \& Hubbard, P. (2013). CALL and learner autonomy: Affordances and constraints. In M. Thomas, H. Reinders, \& M. Warschauer (Eds.), Contemporary computer assisted language learning (pp. 359-375). London, UK: Continuum Books. 
Reinders H. (2010). Twenty Ideas for Using Mobile Phones in the Language Classroom. English Language Teaching Forum, 46(3), 20-25, 33.

Rubin, J. (1975). What the" good language learner" can teach us. TESOL Quarterly, 9, 41-51.

Ryan, R. M., \& Deci, E. L. (2000). Intrinsic and Extrinsic Motivations: Classic Definitions and New Directions. Contemporary educational psychology, 25(1), 54-67.

Salehi, H., Ebrahimi, M., Sattar, S., \& Shojaee, M. (2015). Relationship between EFL Learners' Autonomy and Speaking Strategies They Use in Conversation Classes. Advances in Language and Literary Studies, 6(2), 37-43.

Samida, D. K. (2012). Language learning strategies. TESOL Journal, 159-164.

Seddigh, F., \& Shokrpur, N. (2012). Vocabulary learning strategies of medical students at Shiraz University of Medical Sciences. English Language Teaching, 5(2), 160-173.

Selwyn, N. (2010). Looking beyond learning: Notes towards the critical study of educational technology. Journal of computer assisted learning, 26(1), 65-73.

Su, M.-h. M., \& Duo, P.-c. (2010). EFL learners' language learning strategy use as a predictor for self-directed learning readiness. The Journal of AsiaTEFL, 7(2), 153-176.

Tamer, O. (2013). Students' Readiness for Autonomous Learning of English as a Foreign Language (master's thesis). University of Sunderland, England.

Thornton, P., \& Houser, C. (2003). Using mobile web and video phones in English language teaching: Projects with Japanese college students. In B. Morrison, C. Green \& G. Motteram (Eds.), Directions in CALL: Experience, experiments \& evaluation (pp. 207-224). Hong Kong: English Language Center, Hong Kong Polytechnic University.

Timirbaeva, G. R. (2013). Language learning strategies and their impact on learner autonomy. Paper presented at the International Conference on Interactive Collaborative Learning (ICL), 2013, 621-622.

Wasilewska, J. A. (2012). Language Learning Strategies and the Effectiveness of English Language Teaching at the Tertiary Level Education. Journal of Siberian Federal University, Humanities \& Social Sciences, 5(4), 492-499.

Weinstein, C. E., \& Mayer, R. E. (1986). The teaching of learning strategies. In C. M. Wittrock (Ed.), Handbook of research in teaching (pp. 315-327). New York: Macmillan Publishing Company.

Wenden, A. (1987). How to be a successful language learner: insights and prescriptions from L2 learners. In A. Wenden \& J. Rubin (Eds.), Learner strategies in language learning (pp. 103-117). London: Prentice Hall.

White, C. (1995). Autonomy and strategy use in distance foreign language learning: Research findings. System, 23(2), 207-221. 
Wong, L.-H., Chin, C.-K., Tan, C.-L., \& Liu, M. (2010). Students' personal and social meaning making in a Chinese idiom mobile learning environment. Educational Technology \& Society, 13(4), 15-26. 